\title{
LUPA 2.0: technological evolution for strengthening of the hyperlocal social communication
}

LUPA 2.0: evolução tecnológica para fortalecimento da comunicação social hiperlocal

LUPA 2.0: evolución tecnológica para fortalecer la comunicación social hiperlocal

Claudia Maria Arantes de Assis Saar Doutora em Comunicação Social da Universidade Metodista de São Paulo (UMESP). Professora do curso de jornalismo na Universidade Federal do Amapá. Líder do grupo de pesquisa COMERTEC (Comunicação, Mercado e Tecnologia) e membro do grupo de pesquisa TECCCOG (Tecnologia, Comunicação e Ciências Cognitivas). claudiamaria@unifap.br.

\section{0-0002-5019-8110}

\section{Walter Teixeira Lima Junior Docente do Mestrado Profissional Interdisciplinar em Inovação Tecnológica (PIT) da Universidade Federal de São Paulo (Unifesp) e do Programa de Pós-graduação em Comunicação, Cultura e Amazônia da Universidade Federal do Pará (UFPA). E-mail: walter.lima@unifesp.br. \\ 0000-0002-9423-3854}

Wellington Pacheco Perreira
Mestrando do Programa de Mestrado Profissional
Interdisciplinar em Inovação Tecnológica da
Universidade Federal de São Paulo (Unifesp). E-mail:
wpferreira@unifesp.br.

0000-0002-5628-4917

Correspondência: Universidade Federal do Tocantins, Reitoria, DIRETORIA DE COMUNICAÇÃO. Quadra 109 Norte Avenida NS 15, Plano Diretor Norte, 77001090 Palmas, TO - Brasil.

\author{
Received: 02.16.2021. \\ Accepted: 04.16.2021. \\ Published: 07.01.2021.
}

\begin{abstract}
:
The article analyses the evolution of the Lupa $\mathrm{NH}$ experimental project, with the involvement of teachers and students from the Raimunda dos Passos Santos State School (Amapá/AP). The project focus on creating a system for the configuration of the communicational environment and deliberation for the formation of Hyperlocal Social Intelligence, aiming the collaboration in the insertion of data hyperlocal, and production of journalistic contend with the civic / citizen bias of students, residents, and frequenters of the region, supplying local databases by mobile devices. In the following areas: drinking water; sewage collection and treatment; Street lighting; sidewalks; asphalt; urban cleaning. The paper describes the improved development of version 2.0.
\end{abstract}

KEYWORDS Hyperlocal; Journalism; Application; Citizen; Lupa NH.

\section{Introduction}

The Lupa NH is an experimental project created to encourage the construction of citizenship and political mediation (CASADEI, 2016, p.16), through the social function of communication, with the collaboration of residents, students, and teachers' community of Novo Horizonte, in the city of Macapá (Amapá). The neighborhood was chosen by members of the project for being the second-largest community in terms of population in Macapá, according to current estimates, the number is around 45,000 inhabitants, with numerous infrastructure difficulties in its and public services.

Located in the North Zone of the capital of Amapá, the region was peripheral and was gradually occupied from 1994 (MORAIS et al., 2018, p.94), so that many migrants had access to land and housing, which "only it was made possible through processes of 
occupation of idle land and the self-construction of housing, generating unhealthy settlements, often occupying risk areas" (CARDOSO, 2016, p.29). The disorderly expansion in the North Zone caused negative consequences in the social and environmental spheres for the city and, consequently, also for the neighborhood of Novo Horizonte. The researchers Palheta et. al. (2016) and Carvalho (2013) mention some of these consequences as socio-spatial segregation, lack of public investment, land devaluation, degradation of green areas, and reduced urban environmental quality in cities.

Figure 1 Cartographic Plan of Novo Horizonte neighborhood ${ }^{1}$

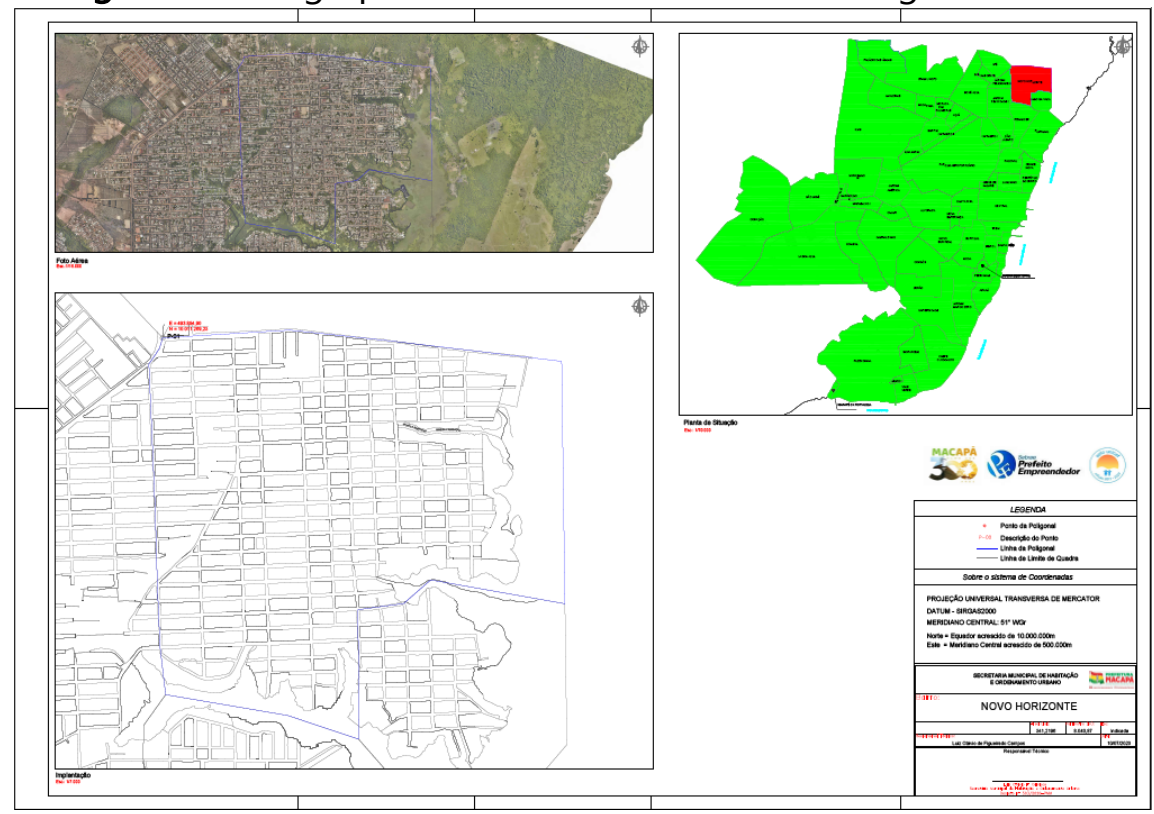

Source: Macapá City Hall. Visited on: March 23rd, 2021.

The public disregard for the region, over the decades, provided the disorganized growth of the neighborhood and the lack of public policies aggravated the social situation. To better understand the needs of Novo Horizonte, surveys were carried out with the Municipality of Macapá, to collect structured data from the region. However, the lack of data on the neighborhood was revealed, which attests to the impossibility of implementing public policy strategies efficiently, effectively, and effectively. The important factor for choosing the neighborhood to implement the project was the historicity of the place with community communication products, such as Rádio Comunitária Novo Tempo and printed newspapers produced by the community. From

\footnotetext{
${ }^{1}$ Available in: <https://macapa.ap.gov.br/consulta-publica-no-001-2020-pmm-delimitacao-e-definicao-dos-bairros-demacapa/\#plantascartograficas> Visited on March 23rd, 2021.
} 
the socio-economic perspective, the beginning of the project modeling took place in 2017, through activities such as meetings, visits to the neighborhood, community radio, and the Raimunda dos Passos Santos State School, which was adopted to be the basis of the project's pilot, involving students and schoolteachers (volunteers), which has 2,500 students. Based on the choice of the neighborhood and the insertions in the region, a theoretical project was modeled, with an interdisciplinary approach, for the creation of an application on cell phones, to provide through a digital geolocation system connected and use the precepts of community communication (PERUZZO, 2007), it is possible to make individuals become producers of the information content of social relevance in a citizen way (BOWMAN; WILLIS, 2003), using connected digital technological tools. In this sense, volunteers, after specific training in handling the application and content production, will be able to acquire autonomy and authority to report their own stories, sometimes ignored by traditional media. As a result, it is hoped that volunteers, knowledgeable about the neighborhood's infrastructure problems, will be able to supply local digital databases to a customized application for mobile devices and/or on the Web, enabling the formation of datasets with structured information about the region.

Therefore, the main objective of the project is the creation and creation of an interconnected public sphere (BENKLER, 2006), composed of "collective cohesion" and the community deliberation process, allowing the formation of a participatory environment through communication technologies connected digital, which makes it possible, if well configured and volunteers are well prepared, to provide "power" to the community, collaboratively influencing local decision-making. This scope can favor civic involvement, co-production, and information sharing to solve the serious social problems in the region. It is important to emphasize the fundamental characteristics of the project. It differs from the purpose of applied research, which is defined "by its practical interest, that is, that the results are applied or used, immediately, in solving problems that occur in reality" (MARCONI; LAKATOS, 2002, p. 20), many of them linked to issues of marketing products and solutions. Thus, the project is structured in the experimental line, as the term says, it aims at experimentation, being "the experiment a situation, created in the laboratory, to observe, under control, the relationship that exists between phenomena" (RUDIO, 1986, p. 60).

With that experimental setup, the project that has as its main characteristic being elaborated collaboratively, without funding, counting on volunteers in all its stages, it starts with the organization of a Hackathon ${ }^{2}$. The event provided the consolidation of

\footnotetext{
2 Hackathon is an event that brings together programmers, designers, and other professionals from software development to work in marathons to build specific solutions for one or several challenges.
} 
technological modeling and the beginning of the first version of the application, being developed in three parts: application for mobile devices and Application Programming Interface (API) with interconnections for the map services in cloud.

\section{Media Ecology: Composing with a Media Ecosystem}

The city of Macapá has a traditional media system, with TV stations (open signal and cable), radio, and printed newspapers. Therefore, following the model consolidated throughout the national territory, with content retransmissions and production of local content, often linked to economic and political interests in the State of Amapá, which configure powerful forces in almost all sectors of society in Amapá.

Combining with the traditional media system, social networks, blogs, and other information devices based on the Internet, they form a hybrid media system, with impact difficult to measure. Social media platforms, such as local Facebook groups, also play an increasingly important role in local media ecology (NYGREN; LECKNER; TENOR, 2018, p.1). However, while the new platforms are important, they do not replace traditional media such as newspapers and broadcast TV and radio, instead, they become a complement and have important functions alongside traditional media platforms. Thus, the system changes to become more 'hybrid', both old and new media change, in the sense of composing and forming a new media ecology (COLEMAN et al., 2016) Chadwick (2013) evidences the existence of a hybrid media system, which is being set up where different forms of local media compete with traditional media, but coexisting in an interdependent way between the new media forms and the established patterns of dissemination of information of social relevance. This communicational context has been conceptualized as New Media Ecology. In concept, both new and old media find new places in the system (ANDERSON, 2016). This hybridity is very important in the correlation of media forces, as there is a decline in local media, which mainly works in small and medium-sized cities. This decrease can be noticed by the reduction in sales of printed journalistic vehicles and even their disappearance, as happened in Santa Catarina, when Diário Catarinense, the newspaper with the largest printed version and widest circulation in Santa Catarina, published since 1986, ceased to be published; the A Notícia, based in Joinville, the largest city in the state, and with circulation since 1923, and also Jornal de Santa Catarina, published in Blumenau since $1971^{3}$.

\footnotetext{
3 Available in: https://www.baguete.com.br/noticias/17/10/2019/santa-catarina-perde-jornais-diarios-impressos Visited on March 27th, 2021.
} 
The concept of Media Ecology has become more important in recent years in media development research. The term arises, derived from the concept "news ecology", due to studies on the influence of blogs, in the early 2002's, which collaborated to the formation of a local public sphere (ANDERSON, 2016). The main assumption of the notion is that media development can only be understood as a complex system and the effects of new media and new digital technologies connected. The definition of a Complex Media System involves understanding that it is a system in which large networks of components, in the case of the media, composed of all types of information vehicles are printed, electronic (TV and Radio), and established on connected digital platforms, " without central control and simple operating rules, they give rise to complex collective behaviors, sophisticated information processing and adaptation via learning or evolution" (MITCHELL, 2009, p.13). In the media ecology system, all "species" are influenced when the balance is shifted between different types of media.

The future of socially relevant information not only depends on the role of traditional news dissemination vehicles with a local bias but also on the integration of media actors in the information ecosystem or the American concept, in the media ecology. These actors arise from pages on social networks, blogs, websites and from actions integrated between these media and other available tools, such as plotting data via Google Maps ${ }^{4}$.

This informative ecosystem, with a socially relevant bias, is providing an erosion of local journalistic capacity that underscores the need to explore how new forms of collaborative, non-profit, and voluntary hyperlocal journalism can complement existing forms of local journalism (JENKINS; NIELSEN, 2018, p. 42).

\section{Hyperlocal and local communication}

With the densification of connected digital technologies, every day we experience a media ecosystem that, although more complex, also seeks to simplify access to information relevant to the citizen. In this space that is difficult to measure, which is the internet, any individual, in any location with Internet access, without government restriction, can insert himself and act virtually in any way he considers pertinent. However, within the technological scopes allowed by connected digital service providers and the standards they impose.

\footnotetext{
${ }^{4}$ Google Maps. Available: < https://www.google.com.br/maps> Visited on March 31st, 2021.
} 
The speed of sharing audiovisuals, photos, audio, and other resources increases dramatically, and these digital assets can be accessed via connected digital devices, reaching users in the most remote places.

The possibility of sharing intensifies communication on a large scale, generating data and memory in a virtual environment. As well as globally, local events also generate data and memory, which can be analyzed, cataloged, and seen as a basis of proximity. These digital data, or virtual memories, can be consulted at any space-time (CASTELLS, 1999), since they are inside the network and can be inserted in a specific context, belonging to a place or region.

This phenomenon can be observed through several interdisciplinary paths, one of which is what Marshall McLuhan (1969) points out when explaining the processes of 'tribalization', 'retribalization' and 'detribalization', which are phases of adaptations and readjustments to the communicational processes. For McLuhan, the "tribalization" phase consists of oral communication in an environment of short distances. Thus, the tribe maintained strong ties and should keep the oral reports so that they would not be lost. This phase strengthens the sense of community. On this point, Michel Maffesoli (2006) expresses that the formation of tribes is carried out from direct relations of interests, a search for identification, be it affective or through the exchange of experiences.

The second phase, "detribalization" emerged in society from writing and printing, as both extended the tribes' ties, and also weakened them, as the tribe could gain access to external information and suffer interference. However, detribalization made it possible to store memory in places beyond the tribe's borders. Thus, memory (data) could be physically stored, transported, and accessed. Unlike tribalization, in which oral accounts could die with whoever carried them in their biological memory.

The third phase of transformation, according to McLuhan (1969), is "retribalization", which made it possible to widen connections, reaching other cultures in a non-linear way, although close relationships with the place of belonging are sought, be they affective relationships, of identification or exchange of experiences, as proposed by Mafessoli (1987). Thus, although the individual is anywhere in the world, at any time, it would be possible to return to his 'tribe'. In retribalization, the understanding of information would always be possible, although it was passed on in a disjointed and disruptive way.

McLuhan did this analysis of retribalization by observing radio and television, however, we can extend this analysis of the third phase also to the use of connected digital networks, since we operate in a globalized and widely connected world that allows us to return to our locality. 
Local information has always had a lot of strength, given that it is one of the criteria based on theories that bring molds of what should or should not be reported, known as newsworthiness criteria. Some authors such as Lippiman (1922), Traquina (2005), Sousa Pinto (2009), among others, bring the importance of information by geographic proximity, that is, information demarcated by borders, physical spaces, or by a neighborhood, a city, a state, or country. In contrast, authors such as Kasper Stieler (1995 WESTERSTÅHL; JOHANSSON, 1994), Golding-Elliot (1979), Hetherington (1985), Erbolato (1985, 2001), Lage (2006, 2001), Warren and Morton (MORTON; WARREN, 1992), Chaparro (1994), and others, only point to the proximity factor - which also considers the affective and belonging ties.

The proximity criterion tells us that the search for local information is important and recurrent. And with the advancement of connected digital technologies, we glimpse how local information is rooted within the global, as in any time and space it is possible to access information from any part of the planet, including retrieving information from the individual's location, being "these new characteristics temporal and spatial, which result in the compression of distances and temporal scales, are between the most important aspects of globalization to affect cultural identities" (HALL, 2014, p.39). In Stuart Hall's view, we should not perceive locality as something amorphic, since locality is not completely delimited or pre-established, since it is infused with cultural processes and identities.

Broadly, globalization has been "connecting communities and organizations in new space-time combinations, making the world, in reality, and in experience, more interconnected" (HALL, 2014, p.39). Thus, glocalization is characterized by the coexistence of flows between geographic (local) and digital (global) spaces. Still, for Stuart Hall, globalization should not destroy identities, "it is more likely that it will simultaneously produce new "global" identifications and new "local" identifications (HALL, 2014, p.45). Thus, the individual appears inserted in a "glocal" context (global + local). This term created by Eugênio Trivinho (2007) points to the sensation of the individual being in contact with the entire planet, a sensation caused especially because of receiving information basically in real-time, as if the physical distances had decreased. And on the other hand, the individual manages to expand to the global, events of his locality.

Supported by the potential and scope of connected digital networks, the latency of local information, and the decline of traditional journalism, hyperlocal communication has been gaining strength among local communities. Thus, hyperlocal "describes original news reporting organizations oriented to 'geographically' native web communities and 
designed to fill perceived gaps in coverage of an issue or region and promote civic engagement (METZGAR; KURPIUS; ROWLEY, 2011, p. .774). As a form of opposition and criticism to the government and local institutions, interacting (PRIMO; TRASEL, 2006), who are active participants in the information process, such as alternative journalists, activists, aspiring journalists, among others, see in hyperlocal communication the opportunity to produce active and participatory materials to decentralize information from consolidated information vehicles that sometimes do not provide opportunities for the population to engage in social issues through information (WILLIANS; HARTE, 2016). Thus, the interactors bring to light information that was not previously widely discussed by government institutions and bodies.

However, Williams and Harte caution that while it is encouraging and important for interactors to produce public journalism, lack of training, as well as funding, can compromise this activity. For them, "as this field of research matures, we believe that more sustained critical attention should be devoted to the study of hyperlocal news production practices in their economic contexts" (WILLIAMS; HARTE, 2016, p.291. Therefore, there is the possibility that citizens, without journalistic training, can help in the formation of the interconnected public sphere, producing information of social relevance based on the social context in which they live.

Thus, public journalism, linked to hyperlocal media, provides more practical information that is beyond the reach of traditional communication. Furthermore, it expands the amount of information available to people, filling content gaps and helping to define local identity. The internet has enabled new informational routes and new ways for geographic communities to connect. Accessing this hyperconnected place is changing the behavior of audiences and facilitating the production and sharing/distribution of content relevant to their community (RADCLIFFE, 2012). Thus, hyperlocal communication has been dealing with themes of social relevance that have a close relationship with the residents and regulars of that area.

\section{The Lupa NH Project}

As described above, the Lupa $\mathrm{NH}$ experimental project began its modeling in 2017 as an extension project at the Federal University of Amapá (Unifap). It was designed to encourage and create opportunities for the citizen participation of students from Bairro Novo Horizonte, in Macapá, through connected digital technologies. For this, a theoretical scope based on hyperlocal communication and geolocation technologies was adopted, with the mobile device (cellular) as an interactive connected media support. 
Thus, using geolocation, and through a mobile application created for this purpose, users of this system can enter data referring to the neighborhood's infrastructure, such as drinking water; sewage collection and treatment; Street lighting; sidewalks; asphalt; urban cleaning. In this way, the application user feeds the database (dataset) that should be used for the construction of news by the citizens of the neighborhood. This process establishes a configuration of communicational environment and deliberation, providing the formation of Hyperlocal Social Intelligence (LIMA JUNIOR, 2017).

With the objective of starting the development of a mobile application, a Hackathon took place in the Web journalism laboratory, of the Journalism course at the Federal University of Amapá (Unifap). The competition, held in 8 hours, was open to Computer Science students, amateurs, professionals, or students from any university. Two members of this action were interested in the continuity of the experiments carried out at the event, the technologist Altemir Almeida and the then Computer Science student at Unifap, Felipe Ferreira. The development of the application was consolidated with the work of programmer Altemir Almeida, who developed version 1.0 of the system, making it available to be on the Android platform. With the tool ready, a workshop was held to present the application to students and teachers at Escola Raimunda dos Passos Santos for a better practical understanding of the use of the tool.

To begin the initial tests in a delimited area of Novo Horizonte neighborhood, on November $16^{\text {th }}$, 2018, a group of students and teachers from Escola Raimunda dos Passos Santos, led by the school's director, teacher Abdinel Rodrigues Ferreira and by teacher Lobão Souza, they went to field to test the application and its features. The action also had students of the Journalism course at Unifap, Christopher Souza and Dellano Carvalho, who became the main collaborators of the project, together with Altemir Almeida. This collaboration process gave rise to the Course Conclusion Work, "Experimental product: educommunication and citizen journalism at the Raimunda dos Passos School, Novo Horizonte, from the hyperlocal application Lupa NH (SOUZA; CARVALHO, 2019), supervised by teacher Cláudia Maria Arantes de Assis Saar, who became a collaborator on the project.

\section{The training of students for journalistic production}

Aiming to train Raimunda dos Passos Santos School students to use the data collected by the Lupa $\mathrm{NH}$ application, on behalf of the community, a group of approximately 25 high school students was trained at the school. This training took place 
through workshops that aimed to produce informative content of social relevance, on social networks, using data collected through the Lupa NH mobile phone application. In this way, they were six workshops offered (Fundamentals of journalism; Journalistic writing; Photojournalism; Radio journalism; Television journalism; Media Convergence). The workshops aimed to teach journalistic practices to students, and that, later, this knowledge could be passed on to other students and to the citizens of the neighborhood. At this moment, when the world is experiencing the Coronavirus pandemic, the continuity of the workshops and the collection of data via the app was completely stopped.

To carry out this part of the project, first, a meeting was held with the director Abdinel Ferreira, the teachers from the school Raimunda dos Passos Santos, Lobão Sousa, and Maria da Conceição Silva Damasceno, with the teacher Cláudia Arantes and the collaborators Christopher Souza and Dellano Carvalho. During the meeting, it was stipulated that the workshops should take place at the school, on Saturdays, from 8 am to $12 \mathrm{pm}$, so as not to compromise the students' curricular activities. As the Lupa NH project has not obtained, so far, any financial support via public notices, all materials, and resources that could not be made available by the school were lent by its teachers, such as data show and computer. In addition, teachers Maria da Conceição, Lobão, and Adbinel prepared snacks for the students during all the workshops since the school's cafeteria is not open on Saturdays.

Based on the Journalism course at Unifap, the preparation of the workshops was coordinated by professor Cláudia Arantes and by the collaborators of the project Lupa $\mathrm{NH}$, Dellano de Carvalho, and Christopher Souza, who recruited 12 students from the journalism course, who stood out in subjects offered in the course. These contents were formatted to be taught in the scope of workshops. Thus, the teaching of content was justified by the opportunity to extract knowledge and learn from that experience, in addition to providing conditions and opportunities for knowledge and perceptions about the journalistic practice to students from that public school. The six workshops were held in pairs to provide greater fluidity and to make them more dynamic. All material prepared for the workshop was previously submitted, revised, and approved by Professor Cláudia Arantes.

Fundamentals of Journalism was the first workshop offered by the project's collaborators, Christopher Souza and Dellano Carvalho. The objective of this workshop was to explain the basic concepts of journalism, human rights, journalists' code of ethics, and the importance of the Access to Information Law, aiming to give a general understanding of the role of journalists and their functions as a professional. 
The second workshop was Journalistic Writing, which, due to its importance, was divided into 2 meetings. In the first, students Beatriz Melo and Marina Guedes addressed the beginning of journalistic production and writing, such as agenda, types of sources, lead, note, news, and report. At the second meeting, students Marina Guedes and Tássia Malena presented literary journalism. During this workshop, students were encouraged to produce different texts for the practice of journalistic writing.

The Photojournalism workshop was taught by students Diego Baleiro and Rudja Santos, who already work professionally, and donated their photographic equipment to teach students how to handle a professional camera. Concepts were also passed on how to produce good photographic images via cell phone. During the workshop, they also taught about the history of photography and photojournalism, photojournalistic genres, in addition to presenting photos that marked the history of photojournalism and the main professionals in the field.

Concepts about Radiojournalism were taught in the fourth workshop. Students Pamela Paolla Gualberto and Jomar Magalhães spoke about the history of radio and how it has adapted to new technologies, demonstrating elements of radio writing, reading and intonation, and the usability of the podcast. As a practice, students from Raimunda dos Passos school were invited to record and edit their audio using free applications for this purpose.

The fifth workshop was about Telejournalism, which was offered by students Benedita Monte, Christopher Souza, and Dellano Carvalho, who taught about the agenda for television, the characteristics of the vehicle, writing for TV, production and recording and editing techniques.

Finally, media convergence, the sixth workshop, led by students Gilzion Reis and Dioni Willian. The use of social media for journalism, how to do community journalism on social media, and how to use Instagram, Facebook, and WhatsApp worked more assertively with students from the public school.

All six workshops showed journalistic theory and practice, seeking to provide students at the Raimunda dos Passos Santos School with greater knowledge for the construction of socially relevant information in the Novo Horizonte neighborhood.

\section{Lupa NH Technology from version 1.0 to 2.0}

The first version of the application (1.0), initially created by Altemir Almeida Silva, Felipe Ferreira, and Anderson Guerra, and improved and consolidated by Altermir 


\section{arevisto Observatório}

Almeida Silva. To build the app, the Visual Studio Code ${ }^{5}$ software was used in the elaboration of all the program codes. To make the commands easier, the JavaScript ${ }^{6}$ programming language was used, which allows for more complex features for your website such as real-time localization, HTML (HyperText Markup Language) ${ }^{7}$, and Cascading Style Sheets (CSS) ${ }^{8}$.

Another important part for the purpose of the application is the system API (Application Program Interface), which is an interface that interconnects services and allows accessing data. In Lupa NH, two are used, the Google Maps geolocation API to create the neighborhood map from the data coming from the application to the MySQL ${ }^{9}$ based database, and the API developed by the project's programmers. After that, the same API transfers to the website all the data collected when requested.

For the information to reach MySQL (Database) it is necessary to activate the Global Positioning System, better known as $\mathrm{GPS}^{10}$, because the app uses geolocation to upload the information provided by residents.

In the application, the user accesses a set of possibilities for entering information, through choices, which is divided into five themes about the neighborhood, chosen by the residents: drinking water, garbage collection, basic sanitation, lighting, and asphalt. With the insertion of informative choices, the data is sent through the API to the Google Maps system and can be viewed, via geolocated data return (marker map), on the application screen. The system is hosted for free and the codes of its first version can be accessed via the GitHub ${ }^{11}$ platform.

\section{Technological evolution}

\footnotetext{
${ }^{5}$ Visual Studio Code is a code editor optimized for building and debugging modern web and cloud applications. Available at <https://code.visualstudio.com/>. Visited March 31st, 2021.

6 JavaScript (often abbreviated as JS) is a structured, high-level scripting interpreted programming language with weak dynamic typing and multiparadigm (prototyping, object-oriented, imperative, and functional). Available at <https://pt.wikipedia.org/wiki/JavaScript>. Visited on March 31st, 2021.

${ }^{7}$ HTML (HyperText Markup Language) is the most basic building block on the web. Defines the meaning and structure of web content. Available https://developer.mozilla.org/pt-BR/docs/Web/HTML. Visited on March 31st, 2021.

${ }^{8}$ Cascading Style Sheets (CSS) is a mechanism for adding style (colors, fonts, spacing, etc.) to a web document. Available at https://pt.wikipedia.org/wiki/Cascading_Style_Sheets. Visited on March 31st, 2021.

${ }^{9}$ MySQL is a database management system (DBMS), which uses SQL (Structured Query Language) as an interface. It is one of the most popular database management systems. Available at <https://pt.wikipedia.org/wiki/MySQL $>$. Accessed March 31st, 2021.

10 Global Positioning System, better known by the acronym GPS (Global Positioning System), is a satellite navigation system that provides a mobile receiver with its position, as well as the time, under any weather conditions, at any time. and anywhere on Earth; As long as the receiver is in the field of view of three GPS satellites (four or more for greater accuracy). Available at <https://pt.wikipedia.org/wiki/Global_positioning_system >. Accessed March 31st, 2021.

${ }^{11}$ Available <https://github.com/wlimajr/lupaNH> Visited on March 31st, 2021.
} 
The technological evolution of the Lupa NH application to version 2.0, still under consolidation, is intended to serve as an instrument for the insertion of local data by the community (geolocation information, text, audio, video, traceroute), which will supply datasets, feeding systems with computational "intelligence" technologies (e.g. machine learning, recommendation systems, geolocation information systems), to return to the community structured information about problems in the region, heating deliberative debates, therefore, serving as an incentive for community participation.

To achieve this technological scope, the process of analysis and gathering of requirements was carried out in the first stage. At this stage, the development of the Lupa NH platform focused on gathering requirements through scenario analysis, rapid prototyping, and unstructured interviews, intending to consider environmental variables and the perspective of the end-user. As a result of this phase, we had 5 base requirements:

- The usage scenarios must consider that the project was designed for needy communities with often deficient basic technological infrastructure. Thus, the implementation of offline storage mechanisms for use without available broadband connection or with low connectivity should be considered, so that once the connection is established, synchronism occurs while maintaining data integrity.

- Users must access, mainly, via mobile devices, through an application, preferably cross-platform. According to StatCounter ${ }^{12} 85.6 \%$ of cell phones in use in Brazil have Android, iOS with 14.13\%, and others with approximately $0.3 \%$. Therefore, compatibility prioritization should be ordered for Android, iOS, and eventual access via browser software.

- Lupa NH must be optimized in its memory usage and local processing capacity, due to the existence of possible hardware restrictions in the access devices, opt, when possible, for server-side processing.

- The application requires access to national territory map services, geolocation sensors for sending geographic coordinates, and having Portuguese as its primary language.

- The platform must contain secure password user authentication and the implementation of access levels. The administrative panel will be accessed

\footnotetext{
12 Available https://gs.statcounter.com/os-market-share/mobile/brazil Visited on December 26th, 2020.
} 
through browser software for data manipulation, reporting, and integration with government systems of public interest.

\section{Application, administration portal, and technologies involved}

The Lupa NH project is a platform consisting of an application for cell phones and a web portal for administration and data management. In the first version (1.0), we opted for a prototype adequate to the basic requirements raised and a segmented architecture in components: frontend and backend. The frontend layer is the interface rendering code for access through mobile apps and browsers, while the backend has all rules, validations, and APIs for accessing the database.

The language of choice for the backend web services was PHP (a recursive acronym for Hypertext Preprocessor), an open-source scripting language. Endpoints integrate the application with the MySQL relational database. Hypertext Markup Language (HTML) and Cascading Style Sheets (CSS) were used to create interfaces along with JavaScript for manipulation of map services, form validation, and automation. Google Maps was the chosen public cloud service, and the source code was made available on the GitHub platform, in the /Altemir-Ap account and the application can be accessed at https://lupanh.labhacker.org.br/app/.

Figure 2 The left screen with home menu and on the right a screen for reporting problems in street lighting 


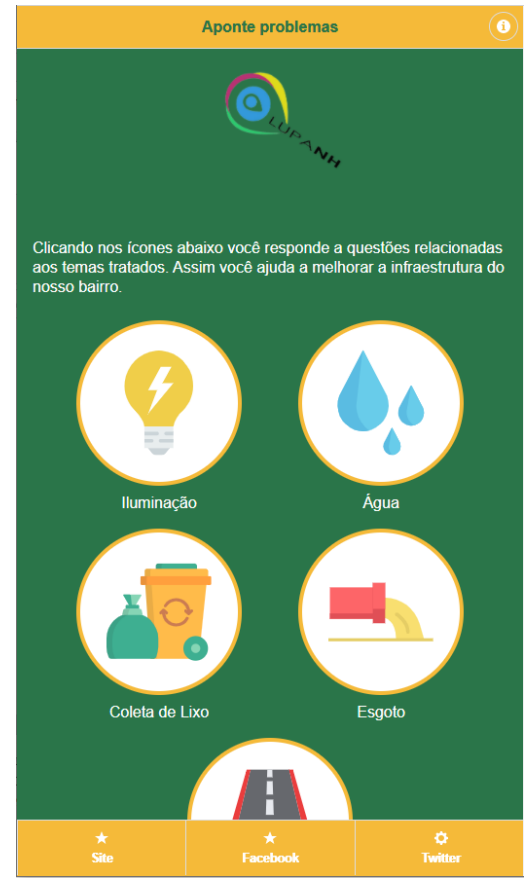
http://dx.doi.org/10.20873/uft.2447-4266.2021v7n3a12en

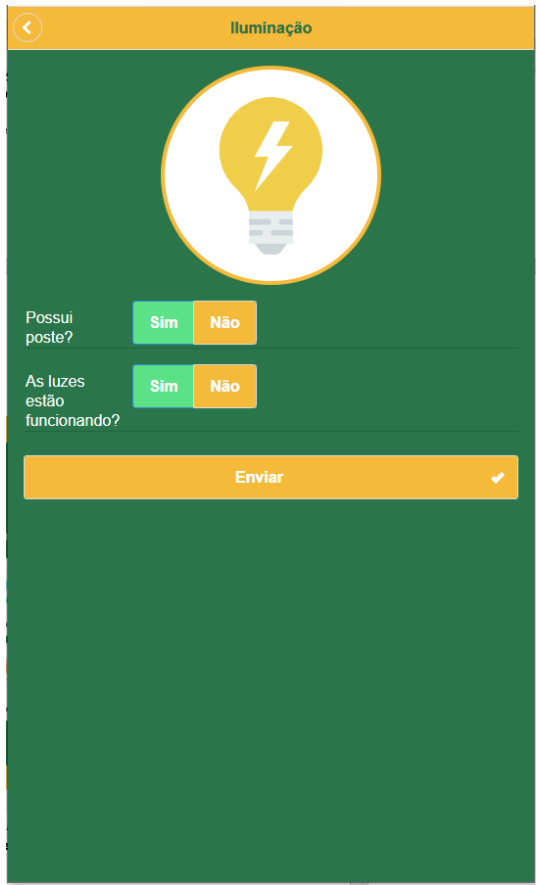

Figure 3 The left screen with a warning message, center home screen menu and on a right information screen
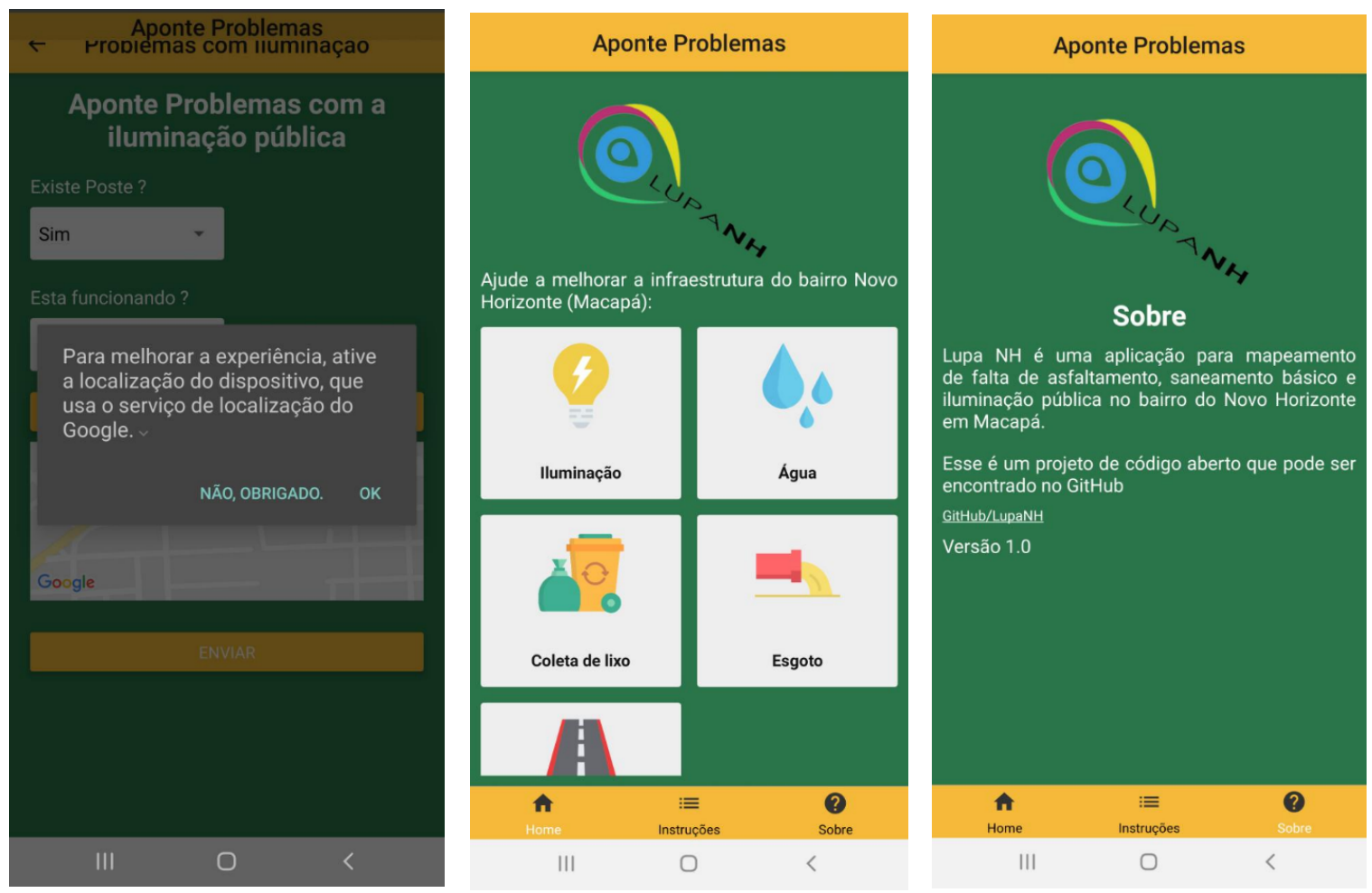
On the platform version 2.0 starts the implementation of a new architecture to the prototype based on the exposure of APIs for access through "clients". Thus, regardless of the technology, application, or "client" software, everyone must be able to make calls through a standard protocol and be independent of both sides to add new evolutionary functionality. The chosen protocol was Representational State Transfer (REST) developed by Roy Fielding, an open standard protocol with the advantage that there is no binding between the backend encoding languages with the systems that make the request.

The interaction with the internet service was implemented through JSON as an information exchange format and the operations defined in HTTP methods, commonly used in REST architectures, are: GET, POST, PUT, DELETE, and PATCH.

The backend development framework chosen was .NET CORE, due to the opensource and the possibility of development for multiple platforms with no major changes to the code. The chosen database was MongoDB, a non-relational open-source database.

Finally, it was decided to segregate the administrative interfaces that must be accessed by browsers from mobile applications, the main reason being the optimization of the user experience and performance gains. The administrative pages continued with rendering by HTML and CSS, however, the application shown in Figure 2 was entirely developed with the React Native JavaScript framework, due to its cross-platform characteristics, and the source code was made available on the GitHub platform, in the account /Lupa-Novo-Horizonte/app.

\section{Future perspectives}

Future versions of Lupa HN can make up for the technical deficits created by the absence of professionals dedicated to the development and budget constraints that resulted in few requirements being fully implemented. Below are some items to consider as future improvements:

- It should focus on the application of methods for prioritizing requirements, in a methodological approach with the assessment of the quality of the software product, according to the users' perception (CORDEIRO; FREITAS, 2011).

- The iterative development with smaller deliveries, but with value to the end-users, will add more agility and evolution of the platform.

- Create separate backend services as per the software engineering standard, With this pattern there is no need for extensive customization of interfaces to suit 
customers. On the other hand, it can generate an additional administrative workload.

- Encryption application end-to-end due to the storage and processing of sensitive user information and later in the integrations with government entities.

- The implementation of Federated Identity will enable the delegation of authentication to a third-party provider such as Facebook, Google, Microsoft, etc. In this way, the development and administration of credentials will be minimized, in addition to facilitating the users' experience.

- Publishing in app stores: Play Store and AppStore.

\section{Conclusions}

The preparation of the Lupa $\mathrm{NH}$ project has a strong direction to encourage the construction of citizenship, through teaching journalistic techniques and the use of technological tools based on a mobile computer system (application), the target audience is students from the Raimunda dos Passos Public School Saints. This citizen construction involves the use of communication as a social function. For this, it counts on high school students from Novo Horizonte neighborhood, in Macapá, which has 45 thousand inhabitants, and with numerous difficulties in its infrastructure and public services.

The theoretical scope of the project favored modeling with an interdisciplinary bias, to account for the complexity of the problem to be tackled by the research: lack of structured data on basic infrastructure in the Macapaense neighborhood. For this, it pointed towards the production of an application for cell phones, intending to provide, through a connected digital geolocation system, adequate technology for the purpose listed in the objective. The work conceptually revisited the precepts of community communication, as with current technological possibilities, it gives individuals the opportunity to transform themselves into producers of informative content of social relevance in a civil way. The project's challenge is the formation of an interconnected public sphere, in a hyperlocal way, with proximity information, working with a hybrid media system, which is being configured in different ways. There is coexistence between local media and traditional media, which coexist interdependently with new media forms, such as social networks and instantaneous communication systems.

To participate in this information ecosystem, with local social relevance, it is necessary to build social capital for communication agents in the state school, which is 
being carried out, and the technological evolution of the Lupa NH application. This new version, 2.0, will serve as an instrument for the insertion of local data by the community (geolocation information, text, audio, video, traceroute), as in version 1.0, which will supply datasets. But the updated version will seek to feed the device with computational "intelligence" technologies, to return to the community structured information about problems in the region, heating deliberative debates, therefore, serving as an encouragement of community engagement.

\section{References}

ANDERSON, C. W. News ecosystems. In: ANDERSON, T.; DOMINGO, C. W.; DAVID \& HERMIDA, A. (Eds.). . The SAGE handbook of digital journalism. London: SAGE, 2016. p. 410-423.

BENKLER, Y. The wealth of networks: how social production transforms markets and freedom. [s.l: s.n.].

BOWMAN, S.; WILLIS, C. Nosotros, el medio: Cómo las audiencias están modelando el futuro de la notícias y la información. Reston, Va: [s.n.]. Available: <https://bit.ly/3jToxog>.

CARDOSO, A. L. Assentamentos precários no Brasil: discutindo conceitos. In: MORAIS, M. D. P.; KRAUSE, C.; NETO, V. C. L. (Eds.). . Caracterização E Tipologia De Assentamentos Precários: Estudos De Caso Brasileiros. Brasília: IPEA, 2016. p. 2952.

CARVALHO, G. M. DE. Crescimento urbano e perda de àreas Verdes em Macapá: riscos e possibilidades de proteção. [s.l.] Universidade Federal do Amapá, 2013.

CASTELLS, M. A era da informação: economia, sociedade e cultura - O poder da identidade. Volume 2 ed. São Paulo: Paz e Terra, 1999.

CHADWICK, A. The hybrid media system: Politics and power. Oxford: Oxford University Press, 2013.

CHAPARRO, M. Pragmática do jornalismo - buscas práticas para uma teoria da ação jornalística. 2. ed. Paz e Terra: Summus, 1994.

COLEMAN, S. et al. The mediated city. The news in a postindustrial context. London: Zed books, 2016.

CORDEIRO, A. G.; FREITAS, L. P. Priorização de requisitos e avaliação da qualidade de software segundo a percepção dos usuários. Ciência da Informação, v. 40, n. 2, p. 160-179, 2011. 
ERBOLATO, M. Técnicas de decodificação em jornalismo: redacção, captação e edição no jornal diário. São Paulo: Ática, 2001.

GOLDING, P.; ELLIOTT, P. Making the news. London, UK: Longman, 1979.

HALL, S. A identidade cultural na pós-modernidade. Rio de Janeiro: Lamparina, 2014. HETHERINGTON, A. News, Newspapers and Television. London: Macmillan, 1985.

JENKINS, J.; NIELSEN, R. K. The Digital Transition of Local News. [s.l: s.n.]. Available: <https://www.digitalnewsreport.org/publications/2018/digital-transition-localnews/>.

LAGE, N. Ideologia e técnica da notícia. Florianópolis: Insular, 2001.

LAGE, N. Estrutura da Notícia. São Paulo: Ática, 2006.

LIMA JUNIOR, W. T. Inteligência Social Hiperlocal: ambiente comunicacional com dados locais gerados pela comunidade, 2017.

LIPPMANN, W. Public opinion. New York, NY: Free Press, 1922.

MAFFESOLI, M. O tempo das tribos: o declínio do individualismo nas sociedades de massa. Rio de Janeiro: Forense, 2006.

MARCONI, M. DE A.; LAKATOS, E. M. Técnicas de pesquisa. 5. ed. São Paulo: Atlas, 2002. MCLUHAN, M. Os meios de comunicação como extensões do homem. São Paulo: Cultrix, 1969.

METZGAR, E. T.; KURPIUS, D. D.; ROWLEY, K. M. Defining hyperlocal media: Proposing a framework for discussion. New Media and Society, v. 13, n. 5, p. 772-787, 2011.

MITCHELL, M. Complexity: A guided tour. New York, NY: Oxford, 2009.

MORAIS, T. O. DE et al. Expansão urbana de Macapá, no Amapá: o caso da zona norte.

Planeta Amazônia: Revista Internacional de Direito Ambiental e Políticas Públicas, v. 10, p. 91-101, 2018.

MORTON, L. .; WARREN, J. Proximity: Localization Vs. Distance in PR News Releases. Journalism and Mass Communication, v. 69, n. Quartely, 1992.

NYGREN, G.; LECKNER, S.; TENOR, C. Hyperlocals and legacy media media: Ecologies in transition. Nordicom Review, v. 39, n. 1, p. 33-49, 2018.

PALHETA, A. C.; SANTOS, T. B. DOS; SERDOURA, F. Segregação ou Integração dos Espaços Públicos Urbanos: uma análise da Zona Norte de Macapá-AP. $7^{\circ}$ Congresso Luso Brasileiro para o Planejamento Urbano, Regional, Integrado e Sustentável-Contrastes, Contradições e Complexidades. Anais...2016 PERUZZO, C. M. K. Direito à comunicação comunitária, participação popular e cidadania. v. 1, n.1 ed. Juiz de Fora (MG): Lumina, 2007.

RADCLIFFE, D. Here and Now: UK hyperlocal media today. London, UK: [s.n.]. RUDIO, F. V. Introdução ao Projeto de Pesquisa Científica. Petrópolis: Vozes, 1986. 
SOUSA PINTO, A. E. Jornalismo diário. São Paulo: Publifolha, 2009.

SOUZA, C. F. DE; CARVALHO, D. R. B. DE. Produto experimental: educomunicação e o jornalismo cidadão na Escola Raimunda dos Passos, Novo Horizonte, a partir do aplicativo hiperlocal Lupa NH. [s.l.] Universidade Federal do Amapá, 2019.

TRAQUINA, N. Teorias do jornalismo - Volume II: A tribo jornalística - uma

comunidade interpretativa transnacional. Florianópolis: Insular, 2005.

WESTERSTÅHL, J.; JOHANSSON, F. Foreign news: News values and ideologies. European

Journal of Communication, v. 9, p. 71-89, 1994.

WILLIANS, A.; HARTE, D. Hyperlocal News. In: WITSCHGE, T. et al. (Eds.). . The SAGE

Handbook of Digital Journalism. City Road, London: SAGE, 2016. p. 1-595.

\begin{abstract}
RESUMO:
O artigo analisa a evolução do projeto experimental Lupa $\mathrm{NH}$, com o envolvimento de professores e alunos da Escola Estadual Raimunda dos Passos Santos (Amapá/AP). O projeto visa criar ambiente comunicacional (conversação) e deliberação para a formação de Inteligência Social Hiperlocal, objetivando a colaboração na inserção de dados hiperlocais e produção de conteúdo jornalístico com o viés cívico/cidadão, abastecendo bases de dados locais, através de aplicativo customizado para dispositivos móveis, com informações sobre infraestrutura nas seguintes áreas: água potável; coleta e tratamento de esgoto; iluminação pública; calçadas; asfalto; limpeza urbana. O trabalho descreve 0 desenvolvimento aprimorado da versão 2.0.

Palavras-Chave: Hiperlocal; Jornalismo; Aplicativo; Cidadão; Lupa NH.
\end{abstract}

\section{RESUMEN:}

El artículo analiza la evolución del proyecto experimental Lupa $\mathrm{NH}$, con la participación de profesores y alumnos de la Escuela Estatal Raimunda dos Passos Santos (Amapá / AP). El proyecto tiene como objetivo crear un ambiente comunicacional (conversación) y deliberación para la formación de Inteligencia Social Hiperlocal, con el objetivo de colaborar en la inserción de datos hiperlocales y producción de contenido periodístico con el sesgo cívico / ciudadano, suministrando bases de datos locales, mediante una aplicación personalizada para dispositivos móviles, con información sobre infraestructura en las siguientes áreas: agua potable; recolección y tratamiento de aguas residuales; iluminación pública; aceras; asfalto; limpieza urbana. El documento describe el desarrollo mejorado de la versión 2.0.

PALABRAS-CLAVES: Hiperlocal; Periodismo; aplicación movil; Ciudadano; Lupa NH. 